\title{
Yetişkin Profesyonel Erkek Futbolcuların Hedonik Açlık ve Beslenme Durumlarının Belirlenmesi
}

\author{
Determination of Adult Professional Male Soccer Player's Hedonic Hunger and Nutritional \\ Status
}

Can Selim Yılmaz ${ }^{1}$, Mendane Saka ${ }^{2}$

Geliş tarihi/Received: 13.05.2019 • Kabul tarihi/Accepted: 21.08.2019

ÖZET

Amaç: Bu çalışma; yüksek şiddetli uzun süreli egzersiz yapan profesyonel futbolcular ile sedanter kontrol grubunun hedonik açlık ve beslenme durumlarını belirleyerek fiziksel aktivitenin hedonik açlı̆̆a etkisini araştırmak amacıyla yapılmıştır.

Bireyler ve Yöntem: Çalışmanın örneklem grubunu Aralık 2018- Mart 2019 tarihleri arasında Türkiye Futbol Federasyonu 1. Lig takımlarından birinde oynayan profesyonel 25 futbolcu ve aynı takımda çalışan 25 sedanter erkek olmak üzere 18-35 yaş arası toplam 50 sağlıklı birey oluşturmuştur. Ayrıca sporcu grubu kendi içerisinde fiziksel olarak aktif ve inaktif oldukları (devre arası tatil dönemi) dönem olarak ikiye ayrılmış ve sonuçlar araştırma kapsamında değerlendirilmiştir. Bireylerin hedonik açlık durumları Besin Gücü Ölçeği (BGÖ) ile saptanmıştır. Beş maddelik bir Likert ölçeği ile cevaplandırılan BGÖ’nün değerlendirme aşamasında toplam ve alt grup puanları 1-5 puan arasında değerlendirilmiştir. Beş puan üzerinden yapılan değerlendirme sonucunda ölçek puanlarının ortalama 2.5’un üzerine çıkması hedonik açlığın varlığını ve besinden etkilenildiğini ifade etmektedir.

Bulgular: Futbolcu (aktif dönem-inaktif dönem) ve sedanter grubun BGÖ ortalama toplam puanları sirasıyla 3.0 \pm 0.62 , $2.5 \pm 0.55,2.4 \pm 0.56$ olarak bulunmuştur. BGÖ toplam puanı ile "besin bulunabilirliği” ve "besinlerin tadına bakılması" alt grup ortalama puanlarının futbolcu aktif grubunda sedanter gruba göre daha yüksek olduğu belirlenmiştir $(p<0.05)$. Futbolcu grubunun aktif döneminde BGÖ toplam puanı ve tüm alt grup puanlarının inaktif oldukları döneme göre daha yüksek olduğu bulunmuştur ( $\mathrm{p}<0.05$ ). Futbolcularda hedonik açlığın ve besinden etkilenmenin sedanter bireylere göre daha yüksek olduğu saptanmıştır ( $\mathrm{p}<0.05$ ). Bireylerin vücut kompozisyonu ile BGÖ toplam puanı arasındaki ilişki futbolcuların aktif döneminde ve sedanter grupta negatif ilişkili bulunurken; futbolcuların inaktif döneminde pozitif ilişkili saptanmıştır $(\mathrm{p}>0.05)$.

Sonuç: Bu çalışma, uzun süreli ve yoğun egzersizin hedonik süreçler üzerinde etkili olabileceğinin bir göstergesi olabilir. Ancak bu konuya ilişkin literatürdeki çelişkili bulgular nedeni ile olası etkileşimi anlamak için daha fazla araştırma yapılması gerekmektedir.

Anahtar kelimeler: Hedonik açlık, futbol, besin gücü, beslenme

1. İletişim/Correspondence: Başkent Üniversitesi, Sağllk Bilimleri Fakültesi, Beslenme ve Diyetetik Bölümü, Ankara, Türkiye

E-posta: dytcanyilmaz@gmail.com • ๑ https://orcid.org/0000-0001-7255-8036
2. Başkent Üniversitesi, Sağlık Bilimleri Fakültesi, Beslenme ve Diyetetik Bölümü, Ankara, Türkiye

은ttps://orcid.org/0000-0002-5516-426X 


\section{ABSTRACT}

Aim: This study has been conducted to investigate the effect of physical activity on hedonic hunger by identifying the hedonic hunger status of the professional soccer players who have a high intensity long term exercise and sedentary control group.

Subjects and Methods: This study was carried out on totally 50 healthy individuals aged between 18-35 years, 25 professional athletes and 25 sedentary control group who are a playing and working in a Turkish Football Federation 1th Division team. Hedonic hunger status of individuals was determined by the Power of Food Scale (PFS).The scores of total and subgroups were calculated between 1 and 5 at evaluation stage of the PFS. As a result of the evaluation made over five points, the mean score of scale is above 2.5 indicates the presence of hedonic hunger and affected from foods.

Results: PFS mean total scores of the soccer players (active period and inactive period) and sedentary group were $3.0 \pm 062$, $2.5 \pm 0.55$ and $2.4 \pm 0.56$, respectively. Mean total score and "food availability", "food tested" subgroup mean scores were found to be higher in active group than sedentary group ( $p<0 ., 05)$. Mean total score and all the subgroup mean scores of the PFS were higher in active period than inactive period in players group $(p<0.05)$. Hedonic hunger and the affected by food were higher in soccer players than sedentary individuals $(\mathrm{p}<005)$. While the correlation between body composition and total score of individuals were negatively related to the active period of the soccer players and the sedentary group, positively related to inactive period of soccer players.

Conclusion: This study may indicate that long-term highly intensive exercise may have an effect on hedonic processes. However, since conflicting findings in literature more research is needed to understand possible interaction.

Keywords: Hedonic hunger, soccer, power of food, nutrition

\section{GíRIŞ}

İnsanlarda yeme davranışı; internal homeostatik mekanizmalar ile düzenlenen bir süreç olmasının yanı sıra çevresel ve sosyal etkenler gibi faktörler ile değişebilen oldukça karmaşık bir durumdur (1). Besinlerin insan vücudu için temel yakıt kaynağ olması ile birlikte, yemek yeme, birçok birey tarafından metabolik ihtiyaçları karşılamaktan çok daha fazlası haline gelmiştir (2). Günümüzde besin bulunabilirliğinin ve besine ulaşılabilirliğin artışı ile yalnızca metabolik olarak değil aynı zamanda sadece zevk ve tatmin için yemek yenilmektedir $(3,4)$. Bilimsel literatürde bu duruma "hedonik yeme, duygusal yeme”, stres kaynaklı yeme, besin bağımlılığı, iyi hissetmek için yeme ve yemekle tedavi” gibi terimler kullanılmaktadır (5).

Metabolik ihtiyaç olmaksızın, mevcut olmayan besinlere karşı yeme isteği duyulması sonucu iştahın açılması ve besinden zevk alma beklentisi durumu "hedonik açlık-yeme" olarak tanımlanmaktadır (2,5). Hedonik yeme dürtüsü ile bireyler metabolik olarak ihtiyaç olmamasına rağmen besin alımına yönelmektedir (2). Bireyin yemek sonrası tok olmasına karşın sevdiği bir tatlıyı tüketmesi bu durum için örnek olarak gösterilebilir (6). Ayrıca bu koşullar altında tüketilen besinler çoğunlukla yüksek şeker, yağ ve tuz içeriği ile lezzetlendirilen yüksek enerjili besinlerdir (7).

Teorik olarak fiziksel aktivitenin, günlük harcanan enerji miktarını artırıp negatif enerji dengesi sağlaması sayesinde vücut ağırlık kontrolünde büyük öneme sahip olduğu bilinmektedir. Ancak oluşan bu enerji açığının yeme dürtüsünde ve enerji alımında artışa neden olabileceği bildirilmektedir (8). Fiziksel aktivitenin, homeostatik mekanizmalara ek olarak besinlerin ödül mekanizması üzerine etkileri ve hedonik tercih üzerindeki etkileri ile iştah kontrolünü etkileyebildiği bildirilmektedir (9). Egzersiz ve besin alımının ödül duyarlılığı ile ilişkili olabileceği düşünülmektedir. Literatür yoğun fiziksel aktivitenin ödül ve bağımlılık ile ilişkili beyin substratlarını uyardığını göstermektedir (10). 
Fiziksel aktivite ve hedonik açlık üzerine olası mekanizmalar incelendiğinde; iştahla ilişkili peptid konsantrasyonlarınınegzersiziledeğişimi,mezolimbik dopaminerjik yolak, telafi edici mekanizmalar, enerji alımının artışının etkili olabileceği düşünülmektedir (11-18).

İştahla ilişkili peptidleri değerlendiren çalışmalarda akut aerobik egzersizi takiben leptin (11-13) ve insülinde $(14,15)$ düşüş; ghrelin ve glukagon benzeri peptid-1 (GLP-1)'de artış bildirilmiştir (14). Cooper et al. (16) tarafindan yapılan çalışmada ise, submaksimal (\%45 $\mathrm{VO}_{2} \max$ ) aerobik egzersiz yaptırllan bireyler sedanter grup ile karşılaştırıldığında 24 saatlik Peptid YY (PYY) seviyesinde artış, 24 saatlik leptin ve insülin seviyelerinde düşüş gözlemlenirken ghrelin seviyesinde değişiklik gözlemlenmemiştir.

Hedonik açlıkta önemli pay sahibi olan mezolimbik dopaminerjik yolak birçok davranışsal durumdan etkilenmektedir. Egzersizin de bu yolağı etkileyen faktörlerden biri olduğu bildirilmektedir. Egzersiz ile birlikte; tirozin hidroksilaz, dopaminerjik reseptör 1 (D1) ve dopaminerjik reseptör 2 (D2) ekspresyonlarının artışına bağlı olarak iştah ve besin alımının arttığı bildirilmektedir (17).

Şiddetli egzersizin, ödül ve bağımlılıkla ilişkili beyin substratlarını uyarabildiği belirtilmektedir. Hedonik süreçlerin, telafi edici yemeye yatkın olanlarda aşırı besin alımını teşvik etme durumunun egzersize bağlı enerji harcaması ile ilişkili olduğu düşünülmektedir (10). Bireyler harcadıkları eforu hedonik tüketim yoluyla telafi etme eğilimindedir. Ayrıca bu eğilimin daha fazla çaba gerektiren bir aktivite sonrası daha fazla olduğu bildirilmektedir (18).

$\mathrm{Bu}$ çalışmanın amacı, yüksek şiddetli uzun süreli egzersiz yapan futbolcular ile sedanter kontrol grubunun hedonik açlık ve beslenme durumlarını belirleyerek fiziksel aktivitenin hedonik açlığa etkisini araştırmaktır.

\section{BİREYLER VE YÖNTEM}

Bu araştırma, Aralık 2018- Mart 2019 tarihleri arasında Türkiye Futbol Federasyonu 1. Lig takımlarından birinde oynayan profesyonel 25 futbolcu ve benzer demografik özelliklere sahip aynı futbol kulübünde çalışan 25 sedanter erkek olmak üzere toplam 50 sağlıklı erkek birey ile yapılmıştır. Bu çalışma için, Başkent Üniversitesi Tıp ve Sağlık Bilimleri Araştırma Kurulu'ndan KA18/328 numaralı araştırma projesi olarak 94603339-604.01.02/38971 sayll karar ile 02/11/2018 tarihli “Araştırma Kurul Onayı” alınmıştır.

Bireylere genel bilgileri içeren, beslenme alışkanlıklarını sorgulayan, besin tüketimlerini saptamaya yönelik besin tüketim kaydı içeren ve fiziksel aktivite durumlarını saptamaya yönelik fiziksel aktivite kaydı içeren anket formu yüz yüze görüşme yöntemiyle uygulanmıştır. Anket formunun içerisinde hedonik açlık durumlarını saptamak ve değerlendirmek için Besin Gücü Ölçeği (BGÖ) yer almaktadır. Ek olarak bireylerin antropometrik ölçümleri araştırmacı tarafından alınmış ve anket formuna kaydedilmiştir. Anket çalışmaya katılan bireylere literatürdeki diğer çalışmalara benzer şekilde, spor kulübüne ait tesis bünyesinde yer alan restoranda birlikte yenen ve aynı besinlerin yer aldığı öğle yemeğinden sonra uygulanmıştır. Antropometrik ölçümler ise gece açlığını takiben sabah aç karına araştırmacı tarafından alınmış ve anket formuna eklenmiştir. Hedonik açlık durumunu belirlemek amacıyla, 2009 yllında Cappelleri et al. (1) tarafindan geliştirilen Power of Food Scale (PFS)'ın Türkçe karşılığı olan ve geçerlilik-güvenirliği yapılan BGÖ kullanılmıştır (19). BGÖ; 1'den (hiç katılmıyorum), 5’e (kesinlikle katılıyorum) kadar değişen beş maddelik bir likert ölçeği ile cevaplandırılan bir ölçektir. BGÖ, besin durumlarına verilen tepkileri ölçen üç alt faktörü (besin bulunabilirliği, besinin varlığı, besinlerin tadına bakma) bulunmaktadır. BGÖ’nün değerlendirilmesi 5 puan üzerinden yapılmakta ve ölçek ortalama puanının 2.5'in üzerine çıkması, hedonik açlığın varlığını ve besinden etkilenildiğini ifade etmektedir (19). 
Antopometrik ölçümler, gece boyu açlığı takiben kahvaltıdan önce ve vücudun sağ tarafından olmak üzere Holtain LTD marka deri kıvrım kalınlığı (skinfold ) kaliperi ile 7 bölgeden (biseps, triseps, subskapula, göğüs, suprailiak, abdominal ve uyluk) deri kıvrım kalınlıkları alınmış ve kaydedilmiştir. Kaydedilen deri kıvrım kalınlıkları, Zorba'nın (20) 7 bölge yağ yüzdesi formülüne yerleştirilerek bireylerin vücut yağ yüzdeleri (\%) hesaplanmıştır. Bel çevresi; araştırmacı tarafindan, birey ayakta, abdomen gevşek, kollar iki yanda, ayaklar yan yana, normal soluk verme sonunda, en alt kaburga kemiği ile kristailiak arası bulunarak orta noktadan geçen çevre ölçümü olacak şekilde, transfers mezura ile yere paralel olarak ölçülmüştür (21). Boy uzunlukları ise birey ayakkabısız, ayakta ve dik pozisyonda, baş ve gözler Frankfurt düzleminde iken stadiometre ile ölçülmüştür (22).

Bireylerin diyetle enerji ve besin ögesi alımlarını saptamak amacıyla kullanılan bir günlük besin tüketim kaydı 24 saatlik hatırlatma yöntemi ile alınmıştır. Besin tüketim kayıtlarının analizi, Türkiye için geliştirilen 'Bilgisayar Destekli Beslenme Programı Beslenme Bilgi Sistemleri 8.1 Paket Programı (BEBİS)" kullanılarak yapılmıştır. Ayrıca hesaplanan enerji ve besin ögesi verileri, yaşa ve cinsiyete göre önerilen Türkiye Beslenme Rehberi-2015 (TÜBER)' e göre değerlendirilmiştir (23).

Fiziksel aktivite durumlarının saptanması amacıyla 24 saatlik fiziksel aktivite durumu kaydı alınmıştır. Fiziksel aktivite kaydı ile her bireye özel bir fiziksel aktivite faktörü (PAL) elde edilmiştir (24). Bireylerin enerji gereksinimleri, bazal metabolizma hızı (BMH) ve fiziksel aktivite faktörü dikkate alınarak hesaplanmıştır. BMH'ın hesaplanması için HarrisBenedict denklemi kullanılmıştır (25).

\section{Verilerin İstatiksel Değerlendirmesi}

Verilerin istatistiksel değerlendirilmesinde SPSS 25.0 istatistik paket programı kullanılmıştır. Araştırma kapsamında ölçüm ile elde edilen sürekli (nicel) değişkenlerden toplanan veriler; ortalama
$(\bar{X})$, standart sapma (SS) ve alt, üst tanımlayıcı istatistikleriyle verilmiştir. Sürekli nicel değişkenlerin normal dağılıma uygunluğu 'KolmogorovSmirnov" testi ile değerlendirilmiştir. Bağımsız iki veya daha fazla grupta kategorik değişkenlerin dağılımının değerlendirilmesi için "ki- kare testi" uygulanmıştır. Bağımsız iki grubun ortalamalarının karşılaştırılmasında, normal dağılıma uygun olanlarda parametrik testlerden "Student t testi", normal dağılıma uygun olmayanlarda "Mann Whitney U testi” kullanılmıştır. Bağımlı örneklerde ise "Wilcoxon t testi” kullanılmıştır. İki sayısal değişken arasında ilişki olup olmadığının araştırılması ve varsa bu ilişkinin yönünün ve şiddetinin belirlenmesi için "Pearson korelasyon analizi" ve "Spearman korelasyon analizi” kullanılmıştır. Bütün hipotez testlerinin analizlerinde önemlilik düzeyi (Tip I hata olasılığı) p $<0.05$ olarak alınmıştır.

\section{BULGULAR}

Çalışmaya katılan bireylerden futbolcuların yaş ortalaması $25.8 \pm 4.73$ yıl iken, sedanter bireylerin yaş ortalaması 29.6 \pm 4.19 ylldır $(\mathrm{p}<0.05)$. Futbolcuların \%76.0'sı lise mezunu ve \%4'ü lisans mezunudur. Sedanter bireylerin \%36’sı lise mezunu, \%60.'ı lisans veya lisansüstü mezunudur ( $\mathrm{p}<0.001)$. Futbolcuların \%24'ü sigara içerken, sedanter bireylerde bu sıklık \%72.0'dir ( $\mathrm{p}<0.05)$. İçilen günlük sigara miktarı; futbolcu grubu için ortalama $16.2 \pm 6.33$ ve sedanter grup için ortalama 11.3 \pm 5.81 adettir $(\mathrm{p}>0.05)$. Futbolcu grubunda alkol tüketenlerin sıklığı \%40.0 iken, sedanter grupta \%48.0' dir. Günlük alınan alkol miktarı futbolcularda 8.0 $\pm 8.61 \mathrm{cc}$ iken, sedanter grup için 8.8 \pm 6.84 cc’dir ( $p>0.05)$.

Çalışmaya katılan bireylere uygulanan BGÖ'den elde edilen sonuçlar ( $\overline{\mathrm{X}}_{ \pm \mathrm{SS}}$ ) Tablo 1'de verilmiştir. Futbolcuların aktif dönemdeki BGÖ toplam puanı ortalama $3.0 \pm 0.64$ puandir. Futbolcular aktif dönemlerinde, ölçeğin birinci alt boyutu olan besin bulunabilirliği alt boyutundan ortalama $2.4 \pm 0.62$ puan; ölçeğin ikinci alt boyutu olan besin mevcudiyeti alt boyutundan $3.0 \pm 0.91$ puan ve üçüncü alt boyutu 
olan besinlerin tadina bakma alt boyutundan $3.7 \pm 0.60$ puan almıştır. Futbolcuların inaktif dönem BGÖ toplam puanı ortalaması $2.5 \pm 0.52$ puandır. Futbolcular inaktif dönemlerinde, ölçeğin birinci alt boyutu olan "besin bulunabilirliği" alt boyutundan ortalama 1.9 \pm 0.61 puan; ikinci alt boyutu olan "besin mevcudiyeti" alt boyutundan $2.6 \pm 0.86$ puan ve üçüncü alt boyutu olan "besinlerin tadına bakma" alt boyutundan ortalama $3.3 \pm 0.65$ puan almıştır. Sedanter bireylerde BGÖ toplam puanı ise ortalama $2.4 \pm 0.56$ ' dır. Sedanter bireyler ölçeğin birinci alt boyutu olan "besin bulunabilirliği" alt boyutundan ortalama $1.7 \pm 0.57$ puan; ikinci alt boyutu olan "besin mevcudiyeti" alt boyutundan $2.8 \pm 0.92$ puan ve üçüncü alt boyutu olan "besinlerin tadına bakma" alt boyutundan ise ortalama $2.8 \pm 0.63$ puan almıştır (Tablo 1).

BGÖ toplam puanı ile besin bulunabilirliği puanı futbolcu grubunun aktif ve inaktif dönemleri arasındaki fark istatistiksel olarak önemlidir ( $\mathrm{p}<0.05)$. $\mathrm{Bu}$ fark futbolcuların aktif dönemleri ve sedanter grup arasında da anlamlı bulunmuştur $(p<0.05)$. Besin mevcudiyeti alt grup puanı futbolcuların aktif ve inaktif dönemleri arasında istatistiksel olarak farklıdır $(p<0.05)$. Üçüncü alt boyut olan besinin tadına bakılması puan ortalaması ise üç grup arasında istatistiksel olarak farklıdır $(\mathrm{p}<0.05)$ (Tablo 1).

Bireylerin vücut kompozisyonu ile BGÖ toplam puanı arasındaki ilişki Tablo 2'de verilmiştir. Futbolcuların aktif döneminde; BGÖ toplam puanı ile vücut yağ yüzdesi, bel çevresi, bel/boy oranı arasında anlamlı bir ilişki saptanmamıştır ( $\mathrm{r}=-0.054, \mathrm{r}=-0.157, \mathrm{r}=-0.039$, $\mathrm{p}>0.05)$. Futbolcuların inaktif döneminde de benzer şekilde, BGÖ toplam puanı ile vücut yă̆ yüzdesi, bel çevresi ve bel/boy oranı arasında anlamlı bir ilişki belirlenmemiştir $(r=0.164, r=0.040, r=0.112$, $\mathrm{p}>0.05)$. Sedanter grupta ise, BGÖ toplam puanı ile vücut yağ yüzdesi, bel çevresi, bel/boy oranı arasında futbolcu grubuna benzer şekilde anlamlı bir ilişki saptanmamıştır ( $\mathrm{r}=-0.216, \mathrm{r}=-0.227, \mathrm{r}=0.297, \mathrm{p}>0.05)$ (Tablo 2).

Tablo 1. Bireylerin BGÖ puan ortalama ve standart sapmaları $\overline{\mathrm{X}} \pm \mathrm{SS}$

\begin{tabular}{|c|c|c|c|c|c|c|}
\hline & \multicolumn{2}{|c|}{ Futbolcu } & \multirow[b]{2}{*}{$\begin{array}{l}\text { Sedanter } \\
(n=25)\end{array}$} & \multicolumn{3}{|c|}{$\mathbf{p}$} \\
\hline & $\begin{array}{l}\text { Aktif dönem } \\
\begin{array}{c}(\mathbf{n}=25) \\
\bar{X} \pm S S\end{array}\end{array}$ & $\begin{array}{c}\begin{array}{c}\text { Inaktif dönem } \\
(\mathrm{n}=25) \\
\overline{\mathrm{X}} \pm \mathrm{SS}\end{array} \\
\end{array}$ & & $\begin{array}{c}\text { Aktif-inaktif } \\
\mathbf{p} \dagger\end{array}$ & $\begin{array}{c}\text { Aktif - } \\
\text { sedanter } \\
\text { p } \dagger \dagger\end{array}$ & $\begin{array}{c}\text { Inaktif- } \\
\text { sedanter } \\
\mathrm{p} \dagger \dagger\end{array}$ \\
\hline BGÖ toplam puanı & $3.0 \pm 0.64$ & $2.5 \pm 0.52$ & $2.4 \pm 0.56$ & $<0.001^{* *}$ & $<0.001^{* *}$ & 0.219 \\
\hline $\begin{array}{l}\text { 1. alt boyut } \\
\text { Besin bulunabilirliği }\end{array}$ & $2.4 \pm 0.62$ & $1.9 \pm 0.61$ & $1.7 \pm 0.57$ & $<0.001^{* *}$ & $<0.001^{* *}$ & 0.218 \\
\hline $\begin{array}{l}\text { 2. alt boyut } \\
\text { Besin mevcudiyeti }\end{array}$ & $3.0 \pm 0.91$ & $2.6 \pm 0.86$ & $2.8 \pm 0.92$ & $0.002^{*}$ & 0.300 & 0.464 \\
\hline $\begin{array}{l}\text { 3. alt boyut } \\
\text { Besinin tadına bakılması }\end{array}$ & $3.7 \pm 0.60$ & $3.3 \pm 0.65$ & $2.8 \pm 0.63$ & $0.001^{* *}$ & $<0.001^{* *}$ & $0.009^{*}$ \\
\hline
\end{tabular}

p†= Bağımlı gruplarda $t$ (Wilcoxon t testi) $p+\dagger=$ Bağımsız gruplarda t testi (Mann Whitney U testi) ${ }^{*} p<0.05{ }^{* *} p<0.001$ BGÖ: Besin Gücü Ölçeği

Tablo 2. Bireylerin vücut kompozisyonları ile BGÖ puanları arasındaki ilişki

\begin{tabular}{|c|c|c|c|c|c|c|}
\hline \multirow{4}{*}{ Vücut kompozisyonu } & \multicolumn{6}{|c|}{ BGÖ Toplam Puanı } \\
\hline & \multicolumn{4}{|c|}{ Futbolcu } & \multirow{2}{*}{\multicolumn{2}{|c|}{ Sedanter $(n=25)$}} \\
\hline & \multicolumn{2}{|c|}{ Aktif dönem (n=25) } & \multicolumn{2}{|c|}{ İnaktif dönem $(n=25)$} & & \\
\hline & $\mathbf{r}$ & $\mathbf{p}$ & $\mathbf{r}$ & $\mathbf{p}$ & $\mathbf{r}$ & $\mathbf{p}$ \\
\hline Vücut yağ yüzdesi (\%) & -0.054 & 0.797 & 0.164 & 0.434 & -0.216 & 0.201 \\
\hline Bel çevresi (cm) & -0.157 & 0.454 & 0.040 & 0.850 & -0.227 & 0.274 \\
\hline Bel/boy & -0.039 & 0.854 & 0.112 & 0.596 & -0.297 & 0.149 \\
\hline
\end{tabular}

$r=$ Pearson korelasyon katsayısı, BGÖ: Besin Gücü Ölçeği 
Tablo 3. Bireylerin diyetle enerji ve makro besin ögesi alımları ile BGÖ puanları arasındaki ilişki

\begin{tabular}{|c|c|c|c|c|c|c|}
\hline \multirow{4}{*}{ Enerji ve besin ögeleri } & \multicolumn{6}{|c|}{ BGÖ Toplam Puanı } \\
\hline & \multicolumn{4}{|c|}{$\begin{array}{l}\text { Futbolcu }(\mathrm{n}=25) \\
\end{array}$} & \multirow{2}{*}{\multicolumn{2}{|c|}{ Sedanter $(n=25)$}} \\
\hline & \multicolumn{2}{|c|}{ Aktif dönem (n=25) } & \multicolumn{2}{|c|}{ İnaktif dönem (n=25) } & & \\
\hline & $\mathbf{r}$ & p & $\mathbf{r}$ & $\mathbf{p}$ & $\mathbf{r}$ & $\mathbf{p}$ \\
\hline Enerji (kkal) & -0.156 & 0.456 & -0.173 & 0.408 & 0.096 & 0.650 \\
\hline Karbonhidrat (g) & -0.023 & 0.914 & -0.049 & 0.816 & -0.100 & 0.634 \\
\hline Karbonhidrat (TE\%) & 0.072 & 0.734 & 0.100 & 0.635 & -0.157 & 0.452 \\
\hline Karbonhidrat (g/kg) & 0.058 & 0.782 & -0.005 & 0.982 & -0.036 & 0.865 \\
\hline Protein $(g)$ & -0.125 & 0.550 & -0.083 & 0.694 & 0.238 & 0.252 \\
\hline Protein (TE\%) & -0.036 & 0.864 & 0.106 & 0.615 & 0.216 & 0.299 \\
\hline Protein (g/kg) & -0.074 & 0.724 & -0.052 & 0.805 & 0.264 & 0.203 \\
\hline Yağ (g) & -0.237 & 0.254 & -0.375 & 0.064 & 0.160 & 0.446 \\
\hline Yağ (TE\%) & -0.088 & 0.676 & -0.308 & 0.134 & 0.066 & 0.755 \\
\hline Doymuş yağ asidi (\%) & 0.089 & 0.674 & -0.219 & 0.293 & 0.190 & 0.362 \\
\hline Çoklu doymamış yağ asidi (\%) & -0.326 & 0.111 & -0.320 & 0.119 & 0.234 & 0.260 \\
\hline Tekli doymamış yağ asidi (\%) & -0.300 & 0.146 & -0.361 & 0.076 & 0.005 & 0.982 \\
\hline Kolesterol (mg) & -0.233 & 0.262 & -0.106 & 0.613 & 0.186 & 0.373 \\
\hline Posa (g) & -0.204 & 0.328 & -0.066 & 0.756 & -0.123 & 0.557 \\
\hline
\end{tabular}

r: Pearson korelasyon katsayısı TE: Toplam enerji, BGÖ: Besin Gücü Ölçeği

Bireylerin diyetle enerji ve makro besin ögesi alımları ile BGÖ toplam puanı arasındaki ilişki Tablo 3'de verilmiştir. Futbolcuların aktif ve inaktif dönemlerinde; toplam enerji alımı (kkal), karbonhidrat (g), protein (g), tekli ve çoklu doymamış yağ asidi (\%), kolesterol (mg), posa alımı (g), enerjinin karbonhidrattan gelen yüzdesi (\%), vücut ağırlığı başına karbonhidrat miktarı (g) ve doymuş yağ asidi (\%) alımı ile BGÖ toplam puanı arasında anlamlı bir ilişki saptanmamıştır ( $p>0.05$ ) (Tablo 3). Sedanter grupta futbolcu grubuna benzer şekilde diyetle enerji ve makro besin ögesi alımları ile BGÖ toplam puanı arasında anlamlı bir ilişki bulunmamıştır ( $p>0.05)$ (Tablo 3).

Bireylerin diyetle mikro besin ögesi alımları ve su tüketimleri (L/gün) ile BGÖ toplam puanı arasındaki ilişki Tablo 4' te belirtilmiştir. Futbolcuların aktif ve inaktif dönemlerinde mikro besin öğesi alımları ve su tüketimleri ile BGÖ toplam puanı arasında anlamlı bir ilişki saptanmamıştır ( $\mathrm{p}>0.05$ ) (Tablo 4).
Sedanter grupta ise yalnızca B6 vitamini ile BGÖ toplam puanı arasında pozitif ilişki saptanırken ( $\mathrm{r}=$ 0.464, p<0.05), diğer mikro besin öğesi alımları ve su tüketimleri ile BGÖ toplam puanı arasında anlamlı ilişki bulunmamıştır ( $>0.05$ ) (Tablo 4).

\section{TARTIŞMA}

Egzersiz yapma ve besin alımının ödül duyarlılığı ile ilişkili olabileceği ve yoğun egzersiz uygulamalarının ödül ve bağımlılık ile ilişkili beyin substratlarını uyarabildiği düşünülmektedir. Besinlere verilen hedonik yanıtın egzersize bağlı değişiklik göstermesi, egzersizin vücut ağırlık kaybı için bir araç olarak düşünülmesinden kaynaklanmaktadır (10). Ancak bu konuda birbiriyle çelişkili bilgiler ve araştırmalar yer almaktadır. Egzersiz sonrası enerji yoğunluğu yüksek besinlerin alımındaki artış ve telafi edici yeme ile bağlantıları bulunurken; bazı araştırmalarda bu görüşün tersine, egzersizin iştah kontrolünün geliştirilmesini ve besin alımının azalmasını sağladığı rapor edilmiştir (26-29). Bu kapsamda bu çalışmada, 
Tablo 4. Bireylerin diyetle mikro besin ögesi alımları ve su tüketimleri ile BGÖ toplam puanları arasındaki ilişki

\begin{tabular}{|c|c|c|c|c|c|c|}
\hline & \multicolumn{6}{|c|}{ BGÖ Toplam Puanı } \\
\hline & \multicolumn{4}{|c|}{$\begin{array}{l}\text { Futbolcu } \\
\end{array}$} & \multirow{2}{*}{\multicolumn{2}{|c|}{ Sedanter $(n=25)$}} \\
\hline & \multicolumn{2}{|c|}{ Aktif dönem (n=25) } & \multicolumn{2}{|c|}{ İnaktif dönem (n=25) } & & \\
\hline & $\mathbf{r}$ & $\mathbf{p}$ & $\mathbf{r}$ & $\mathbf{p}$ & $\mathbf{r}$ & $\mathbf{p}$ \\
\hline \multicolumn{7}{|l|}{ Vitaminler } \\
\hline A vitamini ( $\mu \mathrm{g} / \mathrm{RE})$ & -0.081 & 0.700 & -0.033 & 0.877 & -0.242 & 0.245 \\
\hline E vitamini (mg) & -0.312 & 0.129 & -0.279 & 0.177 & -0.023 & 0.915 \\
\hline Tiamin (mg) & -0.219 & 0.292 & 0.140 & 0.504 & 0.174 & 0.405 \\
\hline Riboflavin (mg) & 0.097 & 0.646 & -0.103 & 0.625 & 0.242 & 0.245 \\
\hline Niasin (mg) & 0.035 & 0.869 & -0.062 & 0.769 & 0.215 & 0.302 \\
\hline Folat (mcg) & -0.126 & 0.550 & -0.056 & 0.790 & 0.089 & 0.672 \\
\hline $\mathrm{B}_{12}$ vitamini (mcg) & -0.150 & 0.474 & -0.042 & 0.841 & -0.287 & 0.165 \\
\hline C vitamini (mg) & -0.036 & 0.866 & -0.069 & 0.742 & -0.219 & 0.293 \\
\hline $\mathrm{B}_{6}$ vitamini (mg) & 0.316 & 0.124 & 0.084 & 0.688 & 0.464 & $0.019 *$ \\
\hline \multicolumn{7}{|l|}{ Mineraller } \\
\hline Potasyum (mg) & -0.071 & 0.736 & -0.171 & 0.414 & 0.055 & 0.794 \\
\hline Kalsiyum (mg) & -0.054 & 0.796 & -0.081 & 0.701 & 0.264 & 0.202 \\
\hline Magnezyum (mg) & -0.147 & 0.483 & -0.244 & 0.240 & 0.244 & 0.239 \\
\hline Fosfor (mg) & -0.297 & 0.150 & -0.141 & 0.502 & 0.373 & 0.066 \\
\hline Demir (mg) & -0.201 & 0.335 & -0.220 & 0.291 & 0.088 & 0.674 \\
\hline Çinko (mg) & -0.221 & 0.289 & -0.079 & 0.707 & -0.123 & 0.557 \\
\hline Su tüketimi (L/gün) & 0.089 & 0.674 & 0.216 & 0.299 & -0.190 & 0.364 \\
\hline
\end{tabular}

r: Pearson korelasyon katsayısı, *p<0.05, BGÖ: Besin Gücü Ölçeği

yüksek şiddetli uzun süreli fiziksel aktivitenin hedonik açlık üzerine etkilerinin araştırılması amaçlanmıştır.

Bu çalışmada, fiziksel aktivite düzeyi ile BGÖ puanları arasında pozitif korelasyon saptanmıştır. Hayzaran'ın (19) üniversite öğrencileri ile yaptığı araştırmada öğrencilerin BGÖ puanları ile haftalık fiziksel aktivite yapma düzeyleri arasında bu araştırmadakibulguların tersi olarak negatif korelasyon görülmüştür. Besin bulunabilirliği ve besinin tadına bakılması alt grup puanları ile fiziksel aktivite düzeyleri arasında bu araştırmadaki bulgulara benzer şekilde pozitif korelasyon görülürken, besin mevcudiyeti alt grup puanı ile negatif korelasyon bildirilmiştir ( $p>0.05)$. $\mathrm{Bu}$ araştırmadan farklı olarak Hayzaran'ın (19) çalışma grubunun üniversite öğrencisi olması ve bu grupta beden-benlik algısı, stres gibi karıştırıcıların yoğun olmasının farklı sonuçlar elde edilmesinde rol oynamış olabileceği düşünülmektedir.
$\mathrm{Bu}$ araştırmada BGÖ toplam puanı ve tüm alt grup puanlarının, futbolcu inaktif dönemine göre aktif dönemde daha yüksek olduğu bulunmuştur. $\mathrm{Bu}$ bulgular, şiddetli fiziksel aktivite ile hedonik açlığın ve besinden etkilenmenin arttığı şeklinde yorumlanmıştır. Blundell et al. (30) araştırmasında fazla kilolu ve obez bireylerde 12 haftalık akut egzersizin besinler üzerindeki istek ve zevk etkileri araştırılmış ve bu araştırmadaki bulgulara benzer yorumlanabilecek şekilde, egzersiz sonrasinda besin için zevk çıktılarında artış bildirilmiştir. Finlayson et al. (31), fazla kilolu ve obez bireylerde 12 haftalık egzersiz programından önce ve sonra, akut egzersizin besinlere karşı isteme ve sevme üzerindeki etkilerine bakmıştır. Çalışma sonucunda, bu çalışma ile benzer şekilde egzersiz sonrası besine karşı sevme çıktılarında artış bildirilmiştir. Gustafson et al. (32) çalışmasında ise, bireylere egzersiz öncesi ve egzersiz sonrası elma ve 
kakaolu islak kek seçenekleri sunulmuş ve tüketimleri gözlemlenmiştir. Araştırmanın sonucunda, elma tercihinin egzersiz sonrasında, öncesine göre düştüğü (\%73.7 ve \%54.6); kakaolu sslak kek tercihinin (\%13.9 ve $\% 20.2$ ) ve her ikisini de tercih etmeyenlerin (\%12.4 ve \%25.2) egzersiz sonrasında, öncesine göre arttığı bildirilmiştir. Bu durum araştırmamızdaki bulguları destekler nitelikte olup, egzersizin ödüllendirici potansiyeli ve mezolimbik yolak üzerindeki uyarıcı etkileri ile hedonik açlık belirteçlerine benzer etkiler göstermesi şeklinde yorumlanabilir. McNeil et al. (29) çalışmasında 16 erkek ve kadın katılımcı aerobik egzersiz, direnç egzersizi sedanter kontrol olmak üzere üç aşamalı olacak şekilde çalışmaya alınmış ve bu aşamaların akut besin ödülü üzerindeki etkileri araştırılmıştır. Çalışma sonucunda, bu araştırmadaki bulguların tersi sayllabilecek şekilde; türünden bağımsız olarak egzersiz sonrası, yüksek ve düşük yağlı besinler için göreceli tercihte sedanter döneme göre düşüş gözlemlenmiştir. Cornier et al. (11) 12 fazla kilolu ve obez bireyin sedanter döneminde ve arkasından 6 ay egzersiz yaptırıldıktan sonraki dönemde beslenme davranışları ve iştah çıktılarına bakmıştır. Çalışma sonucunda 6 aylık kronik egzersiz sonrasında BGÖ puanının, bu araştırmadaki bulguların tersine sedanter döneme göre daha düşük olduğu bildirilmiştir.

$\mathrm{Bu}$ çalışmada, bireylerin vücut kompozisyonları (vücut yağ yüzdesi, bel çevresi, bel/boy) ile BGÖ toplam puanı arasında anlamlı bir ilişki bulunmamıştır. Benzer şekilde, Yeh et al. (33) çalışmasında vücut kompozisyonları (vücut yağ yüzdesi ve BKİ) ile PFS arasında ilişki saptanmamıştır. Espel-Huynh et al. (34) çalışmasında ise bu çalışmadaki bulgulara benzer şekilde, hedonik açlığın BKİ ve vücut yağ yüzdesindeki değişimi tahmin etmede başarısız olduğu sonucunu bildirmiştir. Sporcularda BKİ ile vücut bileşimini değerlendirmek doğru bir yaklaşım olmayacağından bu çalışmada BKİ vücut kompozisyonunun değerlendirilmesinde kullanılmamış ve BGÖ ile ilişkisine bakılmamıştır.
$\mathrm{Bu}$ çalışmada; diyetle enerji, makro-mikro besin ögesi alımları ve günlük su tüketimleri ile BGÖ toplam puanı arasında, sedanter gruptaki B6 vitamini dışında anlamlı bir ilişki saptanmamıştır. Birkaç çalışmada bu çalışmadaki bulguların tersine; karbonhidrat, şeker ve yağ yoğunluğu yüksek besinler ile (çikolata ve ürünleri, pastane ürünleri, cips, fast food, ekmek çeşitleri, hamur işleri, patates kızartması, makarna, dondurma) BGÖ puanı arasında anlamlı pozitif ilişki bildirilmiştir $(19,35,36)$.

Uzun süreli yüksek şiddetli fiziksel aktivite/egzersizin hedonik açlı̆̆a etkisi konusunda literatürde profesyonel futbolcu veya sporcularla yapılmış çalışma bulunmamaktadır. Çalışmalar genellikle sedanter bireylerin fiziksel aktiflik durumuna göre veya sedanter ya da fazla kilolu/obez bireylere egzersiz yaptırma tekniği ile ayırılmış gruplar şeklinde planlanmıştır (19,26-32). Bu nedenle bu çalışma profesyonel sporcularda yapılmış ilk çalışma olma özelliği taşımaktadır. Bu bilgiler ışığında bu çalışma, profesyonel sporcularda hedonik açlık belirteçlerinin egzersiz ile nasıl değiştiğine ve sedanter bireyler ile arasındaki farka yönelik bir görüş sağlayabilir.

Katılımcı sayısının az olması ve gruplar arası yaş ortalaması farkı bu çalışmanın kısıtlılığı olarak düşünülmektedir. Ayrıca sigara içme durumu ve alkol alımı bireylerin hedonik açlık durumlarını etkileyebileceğinden çalışmada bir kısıtlılık oluşturabilir. Ancak profesyonel futbolculara ulaşmanın zorluğu ve çalışmanın uygulama aşamasındaki yaşanabilecek eksik veya yanlış bilgilendirme gibi sorunlar düşünüldüğünde, literatürde benzer şekilde planlanmış bir çalışma bulunmadığından bu çalışma pilot bir çalışma olarak planlanmıştır. Bu nedenle bu çalışma daha geniş çaplı yapılacak benzer çalışmalarla desteklenmelidir.

Çıkar çatışması - Conflict of interest: Yazarlar çıkar çatışması olmadığını beyan ederler. - The authors declare that they have no conflict of interest. 


\section{KAYNAKLAR}

1. Cappelleri JC, Bushmakin AG, Gerber RA, Leidy NK, Sexton CC, Karlsson J et al. Evaluating the power of food scale in obese subjects and a general sample of individuals: development and measurement properties. Int J Obes (Lond).2009;33:913-22.

2. Boggiano MM, Wenger LE, Turan B, Tatum MM, Sylvester MD, Morgan PR et al. Real-time sampling of reasons for hedonic food consumption: further validation of the palatable eating motives scale. Front Psychol. 2015;6:744.

3. Hans-Rudolf Berthoud. Metabolic and hedonic drives in the neural control of appetite: who is the boss? Curr Opin Neurobiol. 2011;21:888-96.

4. Monteleone P, Scognamiglio P, Monteleone AM, Perillo D, Canestrelli B, Maj M. Gastroenteric hormone responses to hedonic eating in healthy humans. Psychoneuroendocrinology. 2013;38:1435- 41.

5. Cushing CC, Benoit SC, Peugh JL, Reiter-Purtill J, Inge TH, Zeller MH. Longitudinal trends in hedonic hunger after Roux-en-Y gastric bypass in adolescents. Surg Obes Relat Dis. 2014;10:125-31.

6. Köse S, Şanlıer N. Hedonik açlık ve obezite. Türkiye Klinikleri J Endocrin. 2015;10(1):16-2.

7. Burgess EE, Turan B, Lokken KL, Morse A, Boggiano MM. Profiling motives behind hedonic eating. Preliminary validation of the palatable eating motives scale. Appetite. 2015;72:66-72.

8. Lluch A, King NA, Blundell JE. Exercise in dietary restrained women: no effect on energy intake but change in hedonic ratings. Eur J Clin Nutr. 1998;52: 3007.

9. Beaulıu K, Hopkins M, Long C, Blundell J, Finlayson G. High habitual physical activity improves acute energy compensation in nonobese adults. Med Sci Sports Exerc. 2017;49(11):2268-75.

10. Finlayson G, Bryant E, Blundell JE, King NA. Acute compensatory eating following exercise is associated with implicit hedonic wanting for food. Physiol Behav. 2009;97:62-7.

11. Cornier MA, Melanson EL, Salzberg AK, Bechtell JL, Tregellas JR. The effects of exercise on the neuronal response to food cues. Physiol Behav. 2012;105(4):102834.

12. Guelfi KJ, Donges CE, Duffield R. Beneficial effects of 12 weeks of aerobic compared with resistance exercise training on perceived appetite in previously sedentary overweight and obese men. Metabolism. 2013;62(2):23543.
13. Martins C, Kulseng B, Rehfeld JF, King NA, Blundell JE. Effect of chronic exercise on appetite control in overweight and obese individuals. Med Sci Sports Exerc.2013;45(5):805-12.

14. Martins C, Kulseng B, King NA, Holst JJ, Blundell JE. The effects of exercise induced weight loss on appetite related peptides and motivation to eat. J Clin Endocrinol Metab. 2010;95(4):1609-16.

15. Rosenkilde M, Reichkendler MH, Auerbach P, Torang $\mathrm{S}$, Gram AS, Ploug $\mathrm{T}$, et al. Appetite regulation in overweight, sedentary men after different amounts of endurance exercise: a randomized controlled trial. J Appl Physiol.2013;115(11):1599-609.

16. Cooper JA, Watras AC, Paton CM, Wegner FH, Adams AK, Schoeller DA. Impact of exercise and dietary fatty acid composition from a high-fat diet on markers of hunger and satiety. Appetite. 2011;56:171-8.

17. Darlington TM, McCarthy RD, Cox RJ, Ehringer MA. Mesolimbic transcriptional response to hedonic substitution of voluntary exercise and voluntary ethanol consumption. Behav Brain Res. 2014;259:313-20.

18. Drenowatz C, Evensen LH, Ernstsen L, Blundell JE, Hand GA, Shook RP et al. Cross-sectional and longitudinal associations between different exercise types and food cravings in free-living healthy young adults. Appetite. 2017;118:82-9.

19. Hayzaran M. Üniversite öğrencilerinin hedonik açlık durumlarının farklı ölçekler ile belirlenmesi [Bilim Uzmanlığı Tezi]. Başkent Üniversitesi Sağlık Bilimleri Enstitüsü, Ankara; 2018.

20. Zorba E. Milli takım düzeyindeki Türk güreşçileri için derialtı yağ kalınlığı denklemi geliştirilmesi [Doktora Tezi]. Marmara Üniversitesi, İstanbul; 1989.

21. Ergün A. Vücut kompozisyonunun belirlenmesi. Yavuzer S, editör. Fizyoloji Pratik Kılavuzu. Antıp AŞ Yayınları; 1999. s. 91-9.

22. Lohman TG, Roche AF, Martorell R. Anthropometric standardization reference manual. Illinois: Human Kinetics; 1991.

23. Türkiye Beslenme Rehberi-2015 (TÜBER). Ankara, T.C. Sağlık Bakanlığı Yayın No: 1031, 2016.

24. Report of a Joint FAO/WHO/UNU Expert Consultation. Human Energy Requirements. Rome: FAO Food and Nutrition Technical Report Series; 2001.

25. Harris JA, Benedict FG. A biometric study of basal metabolism in man. Washington, DC: Carnegie Institute, 1919. 
26. Evero N, Hackett LC, Clark RD, Phelan S, Hagobian TA, Aerobic exercise reduces neuronal responses in food reward brain regions, J Appl Physiol.2012;112:1612-9.

27. Crabtree DR, Chambers ES, Hardwick RM, Blannin AK. The effects of high-intensity exercise on neural responses to images of food. Am J Clin Nutr. 2014;99:258-67.

28. Panek LM, Jones KR, Temple JL, Short term aerobic exercise alters the reinforcing value of food in inactive adults. Appetite. 2014;81:320-9.

29. McNeil J, Cadieux S, Finlayson G, Blendell JE, Doucet E. The effects of a single bout of aerobic or resistance exercise on food reward. Appetite.2015;84:264-70.

30. Blundell JE, Caudwell P, Gibbons C, Hopkins M, Naslund $\mathrm{E}$, King $\mathrm{N}$ et al.Role of resting metabolic rate and energy expenditure in hunger and appetite control: a new formulation, Dis Model Mech. 2012;5(5):608-13.

31. Finlayson G, Caudwell P, Gibbons C, Hopkins M, King M, Blundell J. Low fat loss response after medium-term supervised exercise in obese is associated with exerciseinduced increase in food reward. J Obes. 2011;1-8.
32. Gustafson CR, Rakhmatullaeva N, Beckford SE, Ammachathram A, Cristobal A, Koehler K. Exercise and the timing of snack choice: healthy snack choice is reduced in the post-exercise state. Nutrients. 2018; 10:1941.

33. Yeh J, Trang A, Henning SM, Wilhalme H, Carpenter C, Heber D, Li Z, Food cravings, food addiction, and a dopamine-resistant (DRD2 A1) receptor polymorphism in asian american college students. Asia Pac J Clin Nutr. 2016; 25(2):424-9.

34. Espel-Huynh HM, Muratore AF, Lowe MR. A narrative review of the construct of hedonic hunger and its measurement by the Power of Food Scale. Obes Sci Pract. 2018; 4(3): 238-49.

35. Şarahman C, Ok M, Erişkin bireylerin hedonik açlık durumları ile aşırı besin isteği, dürtüsellik ve benlik saygısı durumları arasındaki ilişkinin incelenmesi, J Tradit Complem Med. 2019;2(2):71-82.

36. Chao A, Grilo CM, White MA et al. Food cravings, food intake, and weight status in a community-based sample. Eat Behav 2014; 15(3): 478-82. 